\title{
New Insights into the Immune Molecular Regulation of the Pathogenesis of Acute Respiratory Distress Syndrome
}

\author{
Chin-Yao Yang ${ }^{1}$, Chien-Sheng Chen ${ }^{2,3}$, Giou-Teng Yiang ${ }^{2,3}$, Yeung-Leung Cheng ${ }^{4,5}$, \\ Su-Boon Yong 6,7,8, Meng-Yu Wu 2,3,* (i) and Chia-Jung Li ${ }^{9, * \text { (iD }}$ \\ 1 Division of Chest Medicine, Kaohsiung Veterans General Hospital, Kaohsiung 813, Taiwan; \\ ycyaoyao@vghks.gov.tw \\ 2 Department of Emergency Medicine, Taipei Tzu Chi Hospital, Buddhist Tzu Chi Medical Foundation, \\ New Taipei 231, Taiwan; holeyeye@yahoo.com.tw (C.-S.C.); gtyiang@gmail.com (G.-T.Y.) \\ 3 Department of Emergency Medicine, School of Medicine, Tzu Chi University, Hualien 970, Taiwan \\ 4 Division of Thoracic Surgery, Department of Surgery, Taipei Tzu Chi Hospital, Buddhist Tzu Chi \\ Medical Foundation, New Taipei City 231, Taiwan; ndmc0928@yahoo.com.tw \\ 5 School of Surgery, Tzu Chi University, Hualien 970, Taiwan \\ 6 Institute of Medicine, Chung Shan Medical University, Taichung 402, Taiwan; yongsuboon@gmail.com \\ 7 Division of Pediatric Allergy, Immunology and Rheumatology, Department of Pediatrics, Show Chwan \\ Memorial Hospital, Changhua 500, Taiwan \\ 8 Department of Nursing, Meiho University, Pingtung 912, Taiwan \\ 9 Research Assistant Center, Show Chwan Memorial Hospital, Changhua 500, Taiwan \\ * Correspondence: skyshangrila@gmail.com (M.-Y.W.); nigel6761@gmail.com (C.-J.L.); Tel.: +886-2-6628-9779 \\ (ext. 42752) (M.-Y.W.); +886-4-725-6166 (ext. 82207) (C.-J.L.)
}

Received: 22 January 2018; Accepted: 14 February 2018; Published: 16 February 2018

\begin{abstract}
Acute respiratory distress syndrome is an inflammatory disease characterized by dysfunction of pulmonary epithelial and capillary endothelial cells, infiltration of alveolar macrophages and neutrophils, cell apoptosis, necroptosis, NETosis, and fibrosis. Inflammatory responses have key effects on every phase of acute respiratory distress syndrome. The severe inflammatory cascades impaired the regulation of vascular endothelial barrier and vascular permeability. Therefore, understanding the relationship between the molecular regulation of immune cells and the pulmonary microenvironment is critical for disease management. This article reviews the current clinical and basic research on the pathogenesis of acute respiratory distress syndrome, including information on the microenvironment, vascular endothelial barrier and immune mechanisms, to offer a strong foundation for developing therapeutic interventions.
\end{abstract}

Keywords: acute respiratory distress syndrome; vascular permeability; NETosis; sepsis

\section{Introduction}

Acute respiratory distress syndrome (ARDS) is a life-threatening lung condition that leads to hypoxia by interfering with the delivery of oxygen from alveoli into the blood [1]. In 1967, the term "adult respiratory distress syndrome" was first promoted by Ashbaugh et al. to describe the condition in 12 patients [2]. Subsequent recognition that this lung condition occurred in patients of all ages led to the coining of the current term, in which "acute" replaced "adult." Several conditions can induce ARDS, such as severe pancreatitis, massive blood transfusion, severe sepsis, pneumonia, and mechanical ventilation [3-7], by damaging epithelial and/or endothelial cells and inducing inflammation. Endothelial dysfunction and local inflammation cause diffuse alveolar injury, leading to bilateral pulmonary infiltrates and severe hypoxemia [8-11]. Severe lung injury may develop into respiratory distress and respiratory failure over the course of hours to days. ARDS is associated with high mortality and morbidity rates, 
which increase with disease severity [12-16]. Despite years of basic and clinical studies, the detailed pathophysiology of the microvascular dysfunction and the micro-inflammatory responses in ARDS remain unclear, especially with respect to the molecular regulation of the immune response. In this review article, we analyze the current basic and clinical studies to offer an overview of the vascular permeability molecular regulation and microenvironment in ARDS. We also summarize the mechanisms of ARDS to provide a strong foundation for the development of novel treatment approaches.

\section{Epidemiologic and Clinical Features}

The incidence of ARDS varies by geographical location and population. In a multicenter prospective cohort study, the age-adjusted incidence estimates ranged from 64 to 86 per 100,000 person-years for moderate to severe ARDS [16]. The rate of ARDS-related mortality increases with the severity of lung injury. A multicenter prospective cohort study by Bellani et al. reported that the rate of hospital mortality was $34.9 \%$ in patients with mild ARDS, $40.3 \%$ for those with moderate ARDS, and $46.1 \%$ for those with severe ARDS [12]. The underlying cause of ARDS is a critical determining factor of the mortality rate. Patients with ARDS rarely die due to respiratory failure alone. In the Bersten et al. [13] study, pneumonia and sepsis were the most common causes of death, accounting for $30 \%$ and $32 \%$ of deaths, respectively. Other etiologies of ARDS accounted for 38\% of deaths, including aspiration (17\%), trauma $(13 \%)$, transfusion $(3.3 \%)$, pancreatitis $(2 \%)$, and drug overdose $(0.7 \%)$ (Figure 1$)$. Infection was a major cause of death in ARDS patients. Severe sepsis is a critical condition caused by inflammatory cascades in response to infectious pathogens [17]. The general inflammatory status also affects, not only ARDS, but hypotension and hypoperfusion of multiple organs. It is especially important to understand the relationship between sepsis and ARDS. Timely treatment of sepsis and prevention of the vicious cycle of ARDS can help to decrease morbidity and mortality.

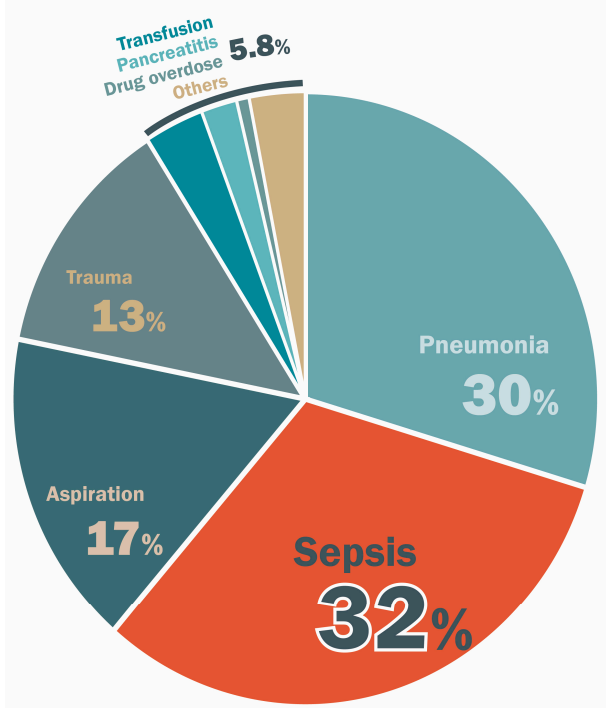

Figure 1. The etiology of acute respiratory distress syndrome (ARDS) (adapted from Bersten et al. [13]).

The clinical features of ARDS progress rapidly within $72 \mathrm{~h}$, resulting in respiratory distress and bilateral alveolar infiltrates [18] that cannot be attributed to cardiogenic causes [19]. In 1994, the American-European Consensus Conference (AECC) proposed the first set of clinical diagnostic criteria for ARDS based on its clinical features (Table 1) [20]. However, the AECC criteria were not clear, due to the inadequate definition of the timing of the disease, poor reliability of image interpretation, and inconsistency in the ratios of the arterial oxygen tension $\left(\mathrm{PaO}_{2}\right)$ to the inspiratory oxygen fraction $\left(\mathrm{FiO}_{2}\right)$. In 2012, the Berlin definition [21] was promoted, with clearer definitions that refined the AECC criteria. The Berlin criteria had improved predictive ability for ARDS-related mortality over the AECC definition [22]. 
Table 1. The diagnostic criteria of the American-European Consensus Conference (AECC) and Berlin definitions.

\begin{tabular}{|c|c|c|}
\hline & AECC Definition from 1994 [20] & Berlin Definition from 2012 [21] \\
\hline Timing & Acute onset & $\begin{array}{l}\text { Within } 1 \text { week of a known clinical insult or new/worsening } \\
\text { respiratory symptoms }\end{array}$ \\
\hline Chest imaging & $\begin{array}{l}\text { Bilateral infiltrates seen on frontal chest } \\
\text { radiograph }\end{array}$ & $\begin{array}{l}\text { Chest X-ray or CT scan: Bilateral opacities not fully } \\
\text { explained by effusions, lobar/lung collapse, or nodules }\end{array}$ \\
\hline Origin of edema & $\begin{array}{l}\text { Pulmonary artery wedge pressure } \\
\leq 18 \mathrm{mmHg} \text { when measured, or no clinical } \\
\text { evidence of left atrial hypertension }\end{array}$ & $\begin{array}{l}\text { Respiratory failure not fully explained by cardiac failure or } \\
\text { fluid overload; objective assessment (e.g., echocardiography) } \\
\text { required to exclude hydrostatic edema if no risk factor } \\
\text { presents }\end{array}$ \\
\hline \multirow[t]{3}{*}{ Oxygenation } & $\begin{array}{l}\text { Acute lung injury criteria: } \mathrm{PaO}_{2} / \mathrm{FiO}_{2} \\
\leq 300 \mathrm{mmHg} \text { (regardless of } \mathrm{PEEP}_{\text {level}} \text { ) }\end{array}$ & $\begin{array}{l}\text { Mild ARDS: } 200<\mathrm{PaO}_{2} / \mathrm{FiO}_{2} \leq 300 \text { with PEEP or } \\
\text { CPAP } \geq 5 \mathrm{cmH}_{2} \mathrm{O}\end{array}$ \\
\hline & $\begin{array}{l}\text { ARDS criteria: } \mathrm{PaO}_{2} / \mathrm{FiO}_{2} \leq 200 \mathrm{mmHg} \\
\text { (regardless of PEEP level) }\end{array}$ & $\begin{array}{l}\text { Moderate ARDS: } 100<\mathrm{PaO}_{2} / \mathrm{FiO}_{2} \leq 200 \text { with } \\
\text { PEEP } \geq 5 \mathrm{cmH}_{2} \mathrm{O}\end{array}$ \\
\hline & & Severe ARDS: $\mathrm{PaO}_{2} / \mathrm{FiO}_{2}: \leq 100$ with PEEP $\geq 5 \mathrm{cmH}_{2} \mathrm{O}$ \\
\hline
\end{tabular}

PEEP: positive end-expiratory pressure, CPAP: continuous positive airway pressure.

\section{Overview of Pathogenesis of ARDS}

ARDS is the result of an initial acute systemic inflammatory response due to direct or indirect lung injury, caused by factors such as smoking, near-drowning, aspiration, sepsis, trauma, ischemia, and exposure to a toxin [23,24]. The severe inflammatory responses induce the change of vascular permeability, leading to acute pulmonary edema. There are three major phases of ARDS: the exudative, proliferative, and fibroproliferative phases [25]. In the exudative phase, the lung injury-induced inflammation cascade increases epithelial permeability, causing diffuse alveolar edema. Hyaline membranes form in the proliferative phase, accompanied by the infiltration of inflammatory cells, including $\mathrm{T}$ cells, neutrophils, and macrophages. After severe damage caused by inflammation and oxidative stress, the extracellular matrix deposited at alveoli accompanied with persisted chronic inflammation. Inflammatory cascades play key roles in processes that are closely involved in ARDS, such as cell apoptosis, proliferation, and migration. Dense fibrosis and a honeycomb-like structure can be detected in fibroproliferative phases of ARDS with imaging studies, such as computed tomography scans or chest $\mathrm{X}$-rays. Due to vascular endothelial and alveolar epithelial damage, the capacity for gas exchange decreases, leading to acute respiratory failure, which may require ventilatory and critical care support. The catastrophic illness associated with ARDS carries a high risk of ventilator-acquired pneumonia, acute myocardial infarction, and acute pulmonary embolism. Below, we provide an overview of the recent advances in the knowledge of the cellular and molecular biology of ARDS, with an aim to facilitate the development of future disease-modifying therapies (Figure 2).

\subsection{Mechanisms of Regulation of Vascular Permeability}

The healthy alveolar epithelium is comprised of two types of cells that form a natural barrier. Type I cells, which make up $90 \%$ of the alveolar epithelium, are sensitive to toxins and oxidative stress. They are easily injured compared to type II cells, which make up $10 \%$ of the alveolar surface area. Type II cells participate in surfactant production and sodium transport, and induce proliferation and differentiation to type I cells. Type II cells also play an important role in innate immunity due to their expression of Toll-like receptors 2 and 4 [26]. The production of surfactant prevents atelectasis and sodium transport keeps fluid out of the alveolus. These functions protect the alveolar microenvironment. Another barrier between the alveolus and capillaries is the microvascular endothelium. Endothelial cells regulate vasoconstriction and dilation via nitrogen oxide formation [27] and also mediate vascular permeability to prevent pulmonary edema by selective transport of fluids, electrolytes, and macromolecules via dynamic opening of the intercellular junctions [28]. The interaction between the 2 separate barriers plays a critical role in controlling fluid accumulation in the alveolar space (Figure 2). Various molecular pathways also regulate vascular permeability, such as 
those involving sphingosine-1-phosphate (S1P), thrombin, and angiopoietin 1 and 2 [29]. S1P, a blood lipid mediator, binds to its receptor, S1P1, to regulate vascular permeability via a Rac-dependent pathway [29,30]. The receptor of thrombin can be cleaved to increase Rho/ROCK signaling, leading to hyperpermeability. Angiopoietin 1 and 2 bind to tyrosine kinase with immunoglobulin-like and EGF-like domains 2 to regulate vascular permeability via the activation of Rho A [31,32].

Lung injury can occur by several mechanisms, especially sepsis. The immune response is triggered by activation of antigen-presenting cells (APCs), such as monocytes, macrophages, dendritic cells, and endothelial cells. These cells respond to pathogens or toxins. After interaction with pathogens or specific pathogen-derived components, APCs present the pathogen-associated molecular patterns to T cells. This signaling activates immune cells to secrete inflammatory mediators, such as tumor necrosis factor (TNF) $\alpha$, interleukin (IL)-1, IL-6, IL-8, prostaglandins, and histamine [33,34]. The inflammatory signaling can be amplified, leading to vascular endothelium dysfunction and the influx of more neutrophils, monocytes, macrophages, and lymphocytes. This causes vascular permeability to increase, accompanied by vasodilatation, via overproduction of nitric oxide by endothelial cells. Severe systemic inflammation-induced lung injury via pulmonary microvascular hyperpermeability is the first step in the development of ARDS. Exudation from the plasma to the alveolar spaces decreases alveolar fluid clearance, leading to lung edema. Severe inflammation also activates infiltrating leukocytes to release potent cytotoxic mediators, such as proteolytic enzymes, granular enzymes, reactive oxygen species (ROS), cytokines, chemokines, and neutrophil extracellular traps (NETs), which minimize the damage to the host when neutrophils kill pathogens. The severe inflammation causes losses of endothelial and epithelial cells by inducing apoptosis and necrosis. Alveolar epithelial cells downregulate ion transport machinery and the production of vascular endothelial growth factor (VEGF), leading to alveolar edema. In addition, gas exchange is blocked by the accumulation of free fluid.

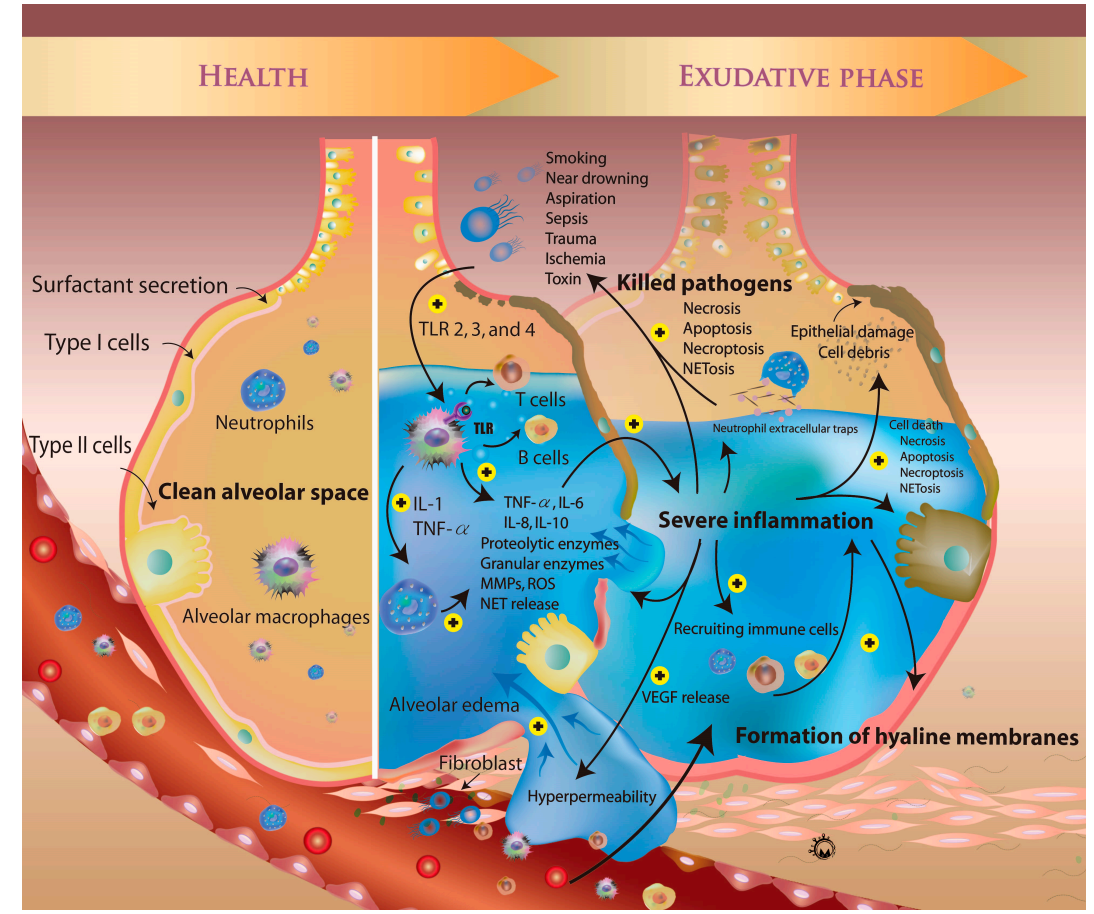

(A)

Figure 2. Cont. 


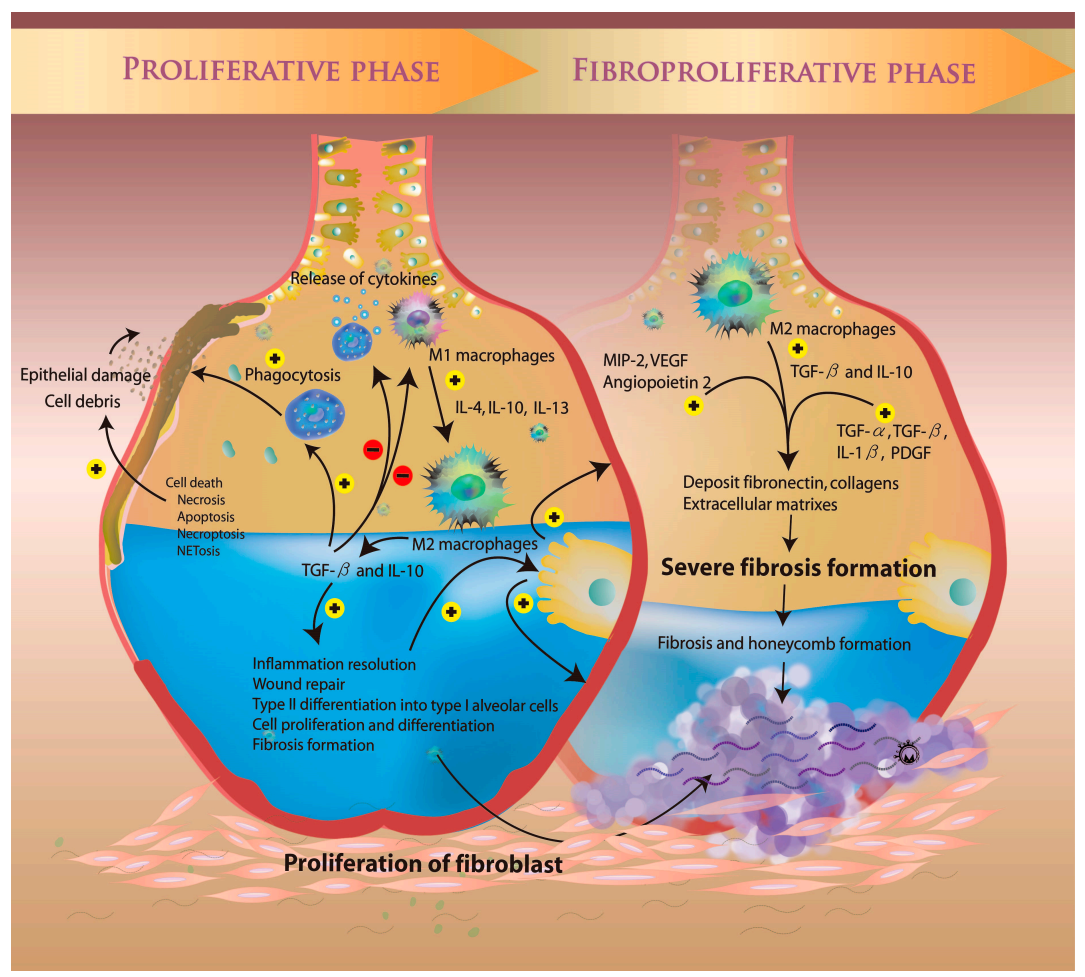

(B)

Figure 2. The molecular regulation of the pathogenesis of acute respiratory distress syndrome in four major phases: (A) Health and exudative phase (B) proliferative phase and fibroproliferative phase.

\subsection{Microenvironment during the Proliferative Phase}

In the proliferative phase, immune cells are recruited to and accumulate in the alveolar space through the capillaries. The release of VEGF, a permeability factor, also plays an important role in the pathogenesis of ARDS by promoting vascular permeability, exudation of protein-rich fluid, and migration of inflammatory cells [35]. A rise in the plasma levels of VEGF causes free fluid to move through the capillary wall into the alveolar space [35-37]. A large number of inflammatory mediators are also released, which cause endothelial cell damage. Apoptosis signaling is activated via the extrinsic and intrinsic pathways. The death ligands, such as TNF- $\alpha$, TNFSF12 (TWEAK), Fas ligand, TNFSF10 (TRAIL), and TNFSF15 (TL1A), activate the extrinsic pathway to induce cell death via the caspase cascade [38]. The ROS from cytokines also activate DNA and mitochondrial damage [39]. The change in the integrity of the mitochondrial membrane activates the pro-apoptotic Bcl-2 family to regulate downstream pro-apoptotic proteins, such as cytochrome c, and cause apoptosis via the intrinsic pathway [40]. In addition, increasing ROS levels induce necroptosis in the setting of ARDS [41-43]. Necroptosis signaling activates the formation of the necrosome via receptor-interacting protein kinase 3 (RIP3) and mixed lineage kinase domain-like protein (MLKL). PARP activation due to DNA damage also leads to necrosome formation. Dead cell debris and protein-rich fluid accumulate in the alveolar space to form the hyaline membrane, which is a characteristic pathological finding in the proliferative phase of ARDS. The presence of hyaline membranes decreases the capacity for gas exchange due to acute lung edema. To recover from lung injury, type II alveolar cells differentiate into type I alveolar cells (Figure 2). The formation of new vascular endothelial cells improves oxygenation via the recovery of microvascular permeability. 


\subsection{The Fibroproliferative Phase of ARDS}

In up to $30-50 \%$ of adult patients, the inflammatory response fails to be resolved in the fibroproliferative phase, leading to the development of fibrosing alveolitis with cystic changes and the limitation of pulmonary function by infiltrating macrophages, fibrocytes, fibroblasts, and myofibroblasts. Many pro-fibrotic agents are released, such as transforming growth factor (TGF) $\alpha$, TGF- $\beta$, IL-1 $\beta$, and platelet-derived growth factor, which causes an imbalanced response to anti-fibrotic mediators, including prostaglandin $E_{2}$ and other growth factors, leading to the deposit of excess fibronectin, collagens, and other extracellular matrix components [44]. The overexpression of angiogenic cytokines and growth factors by immune cells, including macrophage inflammatory protein 2 , angiopoietin 2, and VEGF, may drive the fibroproliferative response (Figure 2) [45-48]. Inadequate mechanical ventilation used to improve gas exchange may also induce fibroproliferation. The shear forces from inadequate mechanical ventilation injure the lung and promote acute and chronic fibroproliferation [49-52]. Persistent, severe damage to the lung structure impairs cellular repair and promotes pathological fibroproliferation. The latest phases of ARDS are characterized by a remodeled lung architecture marked by fibrosis and honeycomb formation [2,25].

In healthy alveoli, the two types of epithelial cell and alveolar macrophage form a natural barrier. When direct or indirect lung injury occurred, the macrophage and neutrophil are activated by Toll-like receptors. Macrophages produce TNF- $\alpha$, IL-1, IL-6, IL-8, IL-10 and recruit neutrophils. The neutrophils release ROS, several enzymes and cytokines. In exudative phase, the severe inflammation lead to higher concentration of VEGF, leading to alveolar edema. The local inflammation also recruits other immune cells and kills pathogens via NETosis, necrosis, apoptosis and necroptosis. Severe inflammatory responses also cause both types alveolar epithelial cells death. In proliferative phase, dead cell debris and protein-rich fluid accumulate in the alveolar space to form the hyaline membrane. The inflammatory reactions resolve via the transition from M1 to M2 macrophages. The M2 macrophages promote wound repair, alveolar epithelial cell transition, and fibrosis formation by release of TGF- $\beta$ and IL-10. In addition, several growth factors, such as MIP-2, angiopoietin, VEGF, and PDGF, also promote the deposition of fibronectin and collagens. The severe fibrosis in fibroproliferative phase leads to lung architecture remodeling marked by fibrosis and honeycomb formation.

\section{The Micro-Inflammatory Response of ARDS}

ARDS is an acute inflammatory disease caused by infectious insult. Pathogens, such as viruses, bacteria, and other microorganisms, are believed to induce pulmonary cell injury, leading to ARDS. Although the detailed mechanisms of ARDS resulting from sepsis or pneumonia remain unknown, the innate immune system is known to play a profound role in the pathophysiology of ARDS [53]. Severe inflammatory responses are induced by pathogens via mediators such as toxins and pathogen-associated molecular patterns. The resulting cell apoptosis, necrosis, and necroptosis produce damage-associated molecular patterns, which lead to the release of heat shock proteins and, ultimately, activate immune reactions [1]. When intracellular innate immune mechanisms fail to control the early infectious process, APCs are activated and phagocytosed the infected cells. Alveolar macrophages are important in the activation of inflammatory cascades. They recruit other immune cells to the injury site and release many pro-inflammatory mediators [1].

\subsection{Role of Alveolar Macrophages in ARDS}

When alveolar macrophages are exposed to infectious agents, they activate the immune response upon recognition of Toll-like receptor ligands, pathogen-associated molecular patterns, and danger-associated molecular patterns [53]. The activated alveolar macrophages can be divided into two main phenotypes: M1 and M2 macrophages [54]. The M1 macrophages encourage inflammation by secreting pro-inflammatory cytokines, such as IL-1 $\beta$, IL-12, TNF- $\alpha$, IFN- $\gamma$, IFN- $\beta$, and inducible nitric oxide synthase. M2 macrophages contribute to tissue repair due to their anti-inflammatory functions, 
mediated by releasing Th2 cytokines, such as IL-4, IL-10, and IL-13 [55,56]. Circulating monocytes and macrophages are recruited to the alveolar space and are activated by macrophage colony-stimulating factor mediators produced by T cells, macrophages, endothelial cells, and fibroblasts. After they phagocytose apoptotic cells, M1 macrophages promote $\mathrm{T}$ cell proliferation by interaction of macrophage-derived CD80/86 and MHC-II with CD28 and T cell receptors, respectively. The interaction also induces neutrophil, macrophage, and monocyte recruitment. M1 macrophages release toxic species, such as nitric oxide, superoxide, and matrix metalloproteinases that cause tissue damage. The TNF- $\alpha$ and IL- $1 \beta$ produced by macrophages also activate neutrophils and induce the overexpression of adhesion molecules, such as intercellular adhesion molecule 1 and vascular cell adhesion molecule 1 , on immune cells and endothelial cells [57-59]. The effects of TNF- $\alpha$ and IL-1 $\beta$ in sepsis are amplified, leading to the recruitment of more inflammatory cells into the alveolar injury site. High concentrations of TNF- $\alpha$ and IL-1 $\beta$ have been reported in the bronchoalveolar lavage fluid of ARDS patients [60,61].

In addition, M1 macrophages transited to M2 macrophages due to the expression of IL-4, IL-10, and IL-13. After pathogen clearance, anti-inflammatory responses mediated by M2 macrophages resolve local inflammation and pulmonary injury. M2 macrophages abrogate pro-inflammatory mediators, induced to augment of TGF- $\beta$ and IL-10, and promote resolution of the immune response and wound repair. TGF- $\beta$ regulates cell proliferation, differentiation, apoptosis, and necroptosis. It also plays an important role in the resolution of pulmonary inflammation and fibrosis formation [62-65]. IL-10 is an anti-inflammatory cytokine that prevents subsequent pulmonary damage by inhibiting the production of pro-inflammatory cytokines, such as IL-1 $\beta$, IL-6, and TNF- $\alpha$, by macrophages [66-69]. In clinical studies, low levels of IL-10 but high levels of TNF- $\alpha$ were reported in the bronchoalveolar lavage fluid of ARDS patients [70,71]. The concentrations of IL-10 and TNF- $\alpha$ in the lung reflect the balance of pro-inflammatory versus anti-inflammatory activity in ARDS.

\subsection{Activated Neutrophils in ARDS}

In ARDS, neutrophils are considered an important component of the inflammatory microenvironment. Several chemokines in the pulmonary injury site, such as IL-8 and IL-17, regulate neutrophil recruitment from vessels into the alveolar space, leading to tissue damage and alveolar-capillary hyperpermeability by releasing toxic ROS and cytokines. In a clinical study, a higher concentration of neutrophils was associated with more severe inflammation, hypoxia, higher permeability, and poor outcome [72]. Activated macrophages release IL-8 and CXCL5, thereby promoting the activation of neutrophils. The lymphocytes also release potent neutrophil chemoattractants, such as IL-1, in sepsis-induced ARDS, resulting in the accumulation of neutrophils in the alveolar space. In in vitro studies, several factors associated with neutrophil recruitment have been reported, including keratinocyte-derived chemokine, cytokine-induced neutrophil chemoattractant, macrophage inflammatory protein 2, CXCL1, CXCL2, and lipopolysaccharide-induced CXC chemokine [73-77]. Excessive neutrophil recruitment occurs in ARDS via alteration of the CD62L expression levels upon decreases in the de-priming mechanisms [78]. After activation, neutrophils that infiltrate alveolar spaces engulf microbes and secrete anti-microbial cytokines and chemokines. Cytokines can activate the endothelium and recruit other circulating leukocytes [79].

The release of 4 types of secretory vesicles from neutrophils-azurophilic (primary), specific (secondary), gelatinase (tertiary), and secretory vesicles-promotes severe local inflammatory at the onset of ARDS. High levels of serine proteases from neutrophils have been reported in the bronchoalveolar lavage fluid and plasma of ARDS patients. The serine proteases and elastases promote the production of pro-inflammatory cytokines by epithelial cells and induce cell apoptosis via the PAR-1-, NF-KB-, and p53-dependent pathways [80-83]. In recent reports, the release of secretory vesicles and ROS from neutrophils induced the formation of NETs to cause NETosis [84]. The binding of alveolar pathogens to neutrophil surface receptors increases the level of cytoplasmic calcium via release from the ER and the opening of membrane channels. The accumulation of calcium activates PKC activity and induces ROS formation from NADPH and nitric oxide production. The oxidative stress 
leads to breakage of the nuclear and granule membranes and the release of NETs. NETs, extracellular fibers networks composed of neutrophil DNA with antimicrobial proteins, were first described in 2004 [85]. NETs bind to extracellular pathogens with minimal damage to host cells. They form protective structures to prevent infection progression in sepsis-induced ARDS. Neutrophil-derived ROS from NADPH oxidase and nitric oxide synthase also induce pulmonary injury in ARDS. Several basic and clinical studies reported that higher tissue levels of ROS led to histological changes in the setting of lung injury and increased alveolar-capillary permeability. ROS also cause endothelial and epithelial cell apoptosis and impair gas exchange.

\subsection{Role of $T$ and $B$ Cells in ARDS}

After APC activation, the cells recruit circulating $\mathrm{T}$ and $\mathrm{B}$ cells to cause inflammatory cascades. Endothelial cells release IL-16 to recruit $\mathrm{CD} 4^{+}$cells and prevent neutrophil recruitment via IL-10. T and B cells are also activated by bacterial lipopolysaccharides, bacterial fragments, or viral DNAs and RNAs, by binding to their surface receptors. They release anti-pathogenic, inflammatory agents, such as interferons and interferon-related proteins, and pro-inflammatory cytokines [1]. However, there are few studies published on the roles of B and T cells in the pathophysiology of ARDS. In an indirect acute lung injury study, acute lung injury was induced in mice lacking B and T cells. The pulmonary injury and cell apoptosis in the deficient group were higher than in the control group. The B and $\mathrm{T}$ cells, therefore, play protective roles. A deficiency in cytotoxic $\mathrm{CD} 8^{+} \mathrm{T}$ cells was also associated with increased pulmonary cell apoptosis. These results are interesting, but require additional clinical and basic investigation and confirmation.

\section{Vascular Endothelial Barrier and Vascular Permeability}

Endothelial cells as the basic structure and function unit of vascular endothelium, one of its important functions is to play its barrier function, together with the extracellular matrix constitutes a complete endothelial cell barrier, regulate the exchange of substances inside and outside the blood vessels, to maintain the stability of the internal environment, making tissues and organs near or far from damage. The integrity of the vascular endothelial barrier relies on both cellular attachment and myosin contractility. Among them, cellular connections mainly include adhesive connections and tight connections. Adhesive junctions form a complex of VE-cadherin and catenin ( $\beta$-catenin, $\gamma$-catenin and p120-catenin); tight junctions consist of proteins such as the transmembrane proteins claudins and ZO-1. Under pathological conditions, the destruction of cell junctions promotes the formation of intercellular cracks. Thus, the combined effect of cell-cell junctions and impaired cell-cell intercellular connections is an important cause of increased vascular permeability [86].

\subsection{Role of Rho/ROCK Signaling Pathway}

Rho GTPases are a class of small GTPases with a relative molecular mass of 20-30 kd and belong to the Ras superfamily. Currently 23 members of the Rho family have been identified, including RhoA, Rac and Cdc42 [87,88]. Rho/Rho-associated protein kinase (ROCK) and inflammatory response are accompanied by the whole process of acute lung injury. In LPS-induced acute lung injury, LPS is an integral part of the outer membrane of Gram-negative bacteria and is one of the key molecules involved in the initial stage of infectious inflammation [89]. Rho can be activated by a variety of cytokines and inflammatory mediators, and Rho/ROCK signaling can be activated by Thrombin, IL-1, TGF- $\beta$, endothelin- 1 and angiotensin II (Figure 3). Previous studies have shown that pretreatment of ROCK inhibitor Y-27632 attenuates endotoxin-induced pulmonary edema and neutrophil migration [90,91]. It has been confirmed that ROCK can act on the VE-cadherin and catenin complex. The claudin-1 and Claudin-4 regulated the adhesion and tight junction of two cell connections. These cytokines and vasoactive substances are important substances that mediate a variety of inflammatory damage. The Rho/ROCK pathway is likely to integrate into the inflammatory signaling pathways mediated by these factors. Furthermore, there is a Rho/ROCK-mediated vascular endothelial injury pathway in ARDS. 


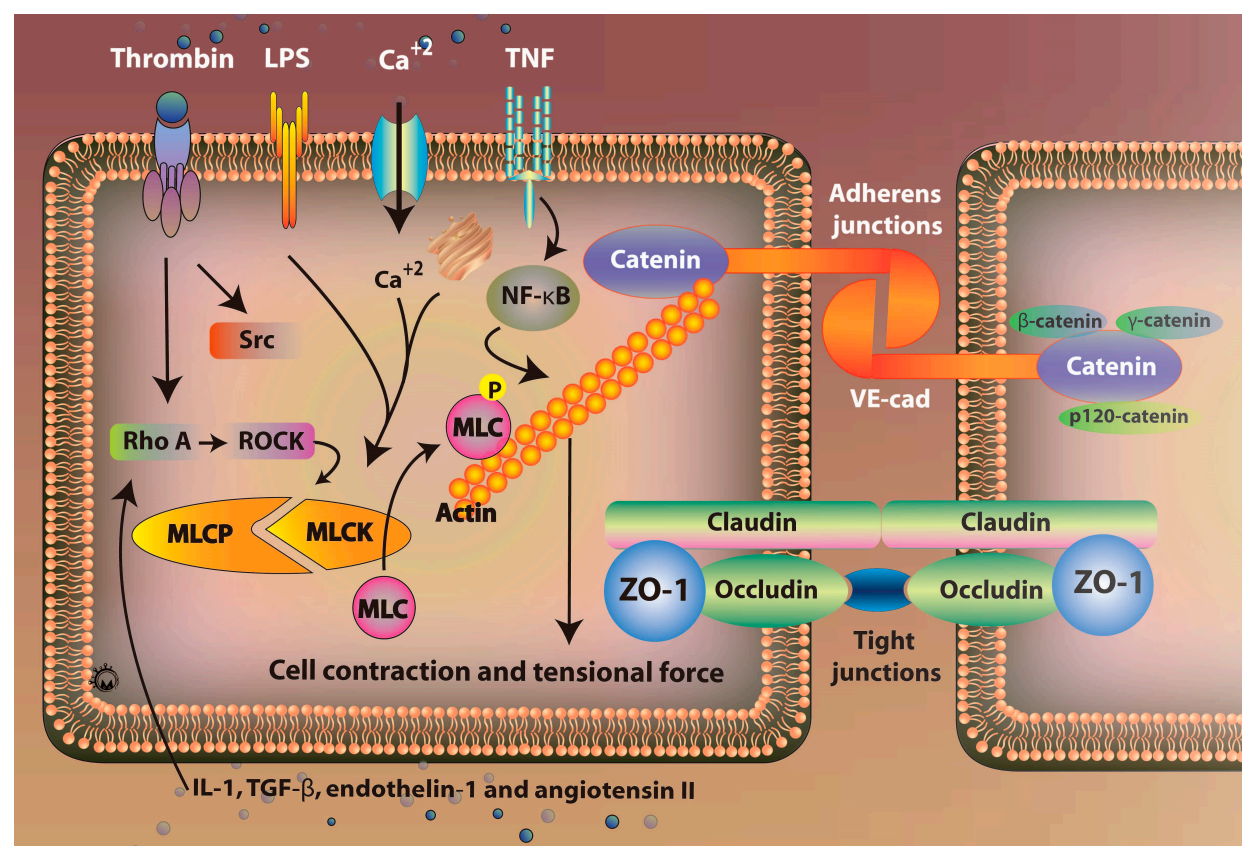

Figure 3. Mechanisms of pulmonary vascular endothelial regulation. Vascular permeability was regulated via actin-myosin interaction. The barrier disruption and enhancement was mediated by the phosphorylation of myosin light chain (MLC) regulated by myosin light chain kinase (MLCK) and myosin light chain phosphatase (MLCP). Activation of the actin myosin increases stress fiber formation and cause in cell contraction and tensional force to adherens junction (AJ). Rho/ROCK signaling can be activated by thrombin, IL-1, TGF- $\beta$, endothelin- 1 and angiotensin II. Activation of RhoA induced ROCK to activate MLCK, causing to enhance vascular permeability. The MLCK also is activated by $\mathrm{Ca}^{2+}$ from endoplasmic reticulum or extracellular space. The TNF and $\mathrm{Ca}^{2+}$ may induced expression of nuclear factor $\mathrm{kB}(\mathrm{NF}-\mathrm{kB})$ causing to degrade the endothelial glycocalyx. The Src signaling mediated VE-cadherin phosphorylation leading to VE-cadherin internalization by activation of thrombin.

\subsection{Role of Claudins Signaling Pathway}

Claudins, a transmembrane protein, has been found to have at least 27 members so far and is an important component of tight junctions (TJs). In tight junctions of epithelial cells, claudins are thought to be key integrin regulators for maintaining potential energy, ion transport selectivity, and the epithelial-endothelial transport mechanisms [92,93]. The complex and tightly linked structures directly affect the permeability of transport ion selective channels and are essential for maintaining barrier function. Disorders in Claudins disrupt barrier function, enhance transport permeability, and further aggravate pulmonary edema and inflammatory responses [94]. When lung tissue is subjected to ischemia/anoxia stimulation, the absence of oxygen during oxidative phosphorylation results in depletion of mitochondrial ATP, and a decrease in cellular energy can disrupt $\mathrm{N}^{+}-\mathrm{K}^{+}$-ATPase that maintains cytoplasmic ion balance, leading to cellular edema [95]. At this time, the pathogenesis of lung injury may be: on the one hand, it can affect the active transport of alveolar fluid by inhibiting the lung water scavenging ability of sodium channels, $\mathrm{N}^{+}-\mathrm{K}^{+}$-adenosine triphosphatase (NKA) and aquaporin (AQP) existing on AEC I/II. However, Claudins, which affect the connection between alveolar epithelium, especially the most directly related to the fluid flow between cells, aggravate pulmonary edema by changing the structure and function of the tight junctions between adjacent epithelial cells [96]. Otherwise, the normal function of ion channels is maintained as the basis of the stable expression of Claudins in the pulmonary epithelial barrier. Studies have shown that the function of NKA and epithelial cell polarity related, and this polarity mainly depends on tight junction formation and E-cadherin of exogenous expression. NKA regulates RhoA-mediated actin polymerization, 
which activator of actin polymerization provides the necessary impetus for the displacement of the tight junction between the apical and baso-epicardial regions. In conclusion, NKA is crucial in the formation and maintenance of tight junctions, and its mechanism relies in part on intracellular ionic homeostasis and eventually epithelial integrity [97].

\section{Therapeutic and Molecular Interventions}

Preventing tissue hypoperfusion and maintaining adequate gas exchange are important in ARDS $[98,99]$. The specific management of ARDS includes improving gas exchange and correcting the underlying pulmonary injury. Many pharmacologic therapies, such as glucocorticoids, surfactants, antioxidants, and anti-inflammatory agents, have been evaluated in Phase II and Phase III trials for ARDS [100-102]. Although no statistically effective treatments for ARDS have been reported, some treatments may have induced responses in subgroups of patients. Supportive treatments for ARDS, including sedation, nutrition support, and prophylaxis against other infectious diseases, decreased the ARDS mortality rate in studies in the 1990s [26,103,104]. Lung-protective ventilation has been reported to prevent barotrauma and late pulmonary injury in in vitro studies. Many animal studies reported high tidal volumes with high inspiratory pressures, leading to histological changes with formation of hyaline membranes. In that study, severe local inflammatory responses were noted, which caused progression to respiratory failure. Lung-protective ventilation decreased ARDS mortality by $3 \%$ [105]. In early studies, patients who received mechanical ventilation with appropriate positive end-expiratory pressure (PEEP) experienced improved oxygenation and reduced hypoperfusion due to the opening of collapsed alveoli and decreased intrapulmonary shunting. Low PEEP may also decrease ventilator-associated pneumonia and prevent pulmonary injury [106]. In ARDS patient, PEEP was applied at $\geq 5 \mathrm{~cm} \mathrm{H}_{2} \mathrm{O}[107,108]$. The major benefit in this population is the improvement in gas exchange by preventing alveolar collapse. High PEEP levels decrease repetitive alveolar opening and closing, but could potentially promote pulmonary injury [108]. Current studies do not recommend the application of high PEEP as a routine initial treatment in the ARDS population $[8,109]$.

\subsection{Corticosteroid}

The effects of anti-inflammatory treatments in ARDS are inconclusive despite several clinical and basic studies over many decades. In current studies, no pharmacologic therapy for ARDS has been reported to statistically improve the rates of morbidity and mortality. Several anti-inflammatory treatments, including inhaled corticosteroids, angiotensin-converting enzyme inhibitors, and peroxisome proliferator-activated receptor agonists, have been tested to control mortality in ARDS. Corticosteroids have been reported to improve lung compliance in in vitro studies [101,110-112]. The corticosteroids inhibited general inflammation by decreasing the production of prostaglandin via activation of annexin I, which is an anti-inflammatory protein that inhibits cytosolic phospholipase A2a to block the production of arachidonic acid [113,114]. Corticosteroids also induce MAPK phosphatase 1 to inhibit cytosolic phospholipase A2a via blocking MAPKs and MAPK-interacting kinase. In addition, corticosteroids inhibit c-Jun, Fos, and NF-KB signaling to reduce the release of cytokines to control systemic inflammatory responses. Due to the complex anti-inflammatory effects of steroids, they have been used to treat allergic responses, autoimmune diseases, and inflammatory diseases in clinical practice. In ARDS, the corticosteroids controlled pulmonary inflammation and improved oxygenation $[115,116]$. However, in some studies, the beneficial effects of the therapeutic corticosteroids were not statistically significant $[117,118]$. In the future, large sample, randomized, controlled trials are necessary to examine the effects and efficiency of corticosteroids.

\subsection{Angiotensin}

Angiotensin, a peptide hormone, is part of the rennin-angiotensin system that regulates vasoconstriction to maintain blood pressure via several mechanisms, such as sympathetic nervous stimulation and release of aldosterone [119]. Initially, angiotensinogen is produced and released into 
the plasma from the liver. It is cleaved by renin, which is produced by the kidneys, to form angiotensin I. Angiotensin-converting enzyme, which is distributed on the pulmonary capillary endothelium, cleaves angiotensin I to produce the octapeptide angiotensin II, which is equipped with several biological effects to mediate vasoconstriction via the specific angiotensin II receptor type 1 and type $2[120,121]$. Angiotensin-converting enzyme plays a critical role in regulating vasoconstriction and vessel permeability. In ARDS, pulmonary endothelial injury decreases the body's ability to convert angiotensin I to II [26,122,123], leading to the theory of angiotensin II insufficiency in ARDS patients. Initially, inflammatory events induce acute lung injury and endothelial injury. Angiotensin-converting enzyme dysfunction leads to angiotensin II insufficiency and catecholamine resistance [26,123]. Angiotensin II insufficiency decreases NF-kB gene expression, which block the renin-angiotensin axis. In an animal study, treatment with recombinant angiotensin-converting enzyme 2 in wild-type and knockout mice partially prevented lung injury, and ameliorated acute lung injury in wild-type mice [124].

\section{3. mTOR}

The PI3K signal transduction pathway plays an important role in many pathophysiological processes such as cell proliferation, apoptosis, migration, vesicle transport and malignant transformation of cells. The PI3K/Akt/PKB signaling pathways and the regulation of apoptosis play an important role. Previous studies found that lipopolysaccharide induced rat alveolar type II epithelial cells can increase PI3K/Akt signaling pathway in Nedd4-2 protein and phosphorylated Akt and cAMP/cCMP related proteins regulate lung epithelial cell apoptosis performance, but significant increase the area of pulmonary edema and lung tissue damage [2]. At the same time, the study confirmed that Th17 cells were significantly decreased either through inhibition of mTORC1 or its upstream (PI3K/AKT) [125]. The mTOR pathway is activated by a variety of different classes of stimuli: it senses cellular energy levels by monitoring the cellular ATP:AMP ratio, insulin and signals from the Wnt pathway [126]. Following receptor engagement, PI3K as a messenger to activate downstream targets including the kinase Akt. Ras homolog enriched in brain (RHEB) plays critical roles in the activation of $\mathrm{mTOR}$, a serine/threonine kinase that is involved in the activation of protein synthesis and growth. RHEB is controlled by the GTPase-activating protein (GAP) activity of a complex consisting of tuberous sclerosis complex 1 (TSC1) and TSC2. TSC2 is phosphorylated and inactivated by Akt and the TSC1-TSC2 complex negatively regulates the kinase mTOR. When this complex is phosphorylated by Akt or Erk1/2, its GAP activity is inhibited and RHEB is active, leading to the activation of mTORC1 [127]. These results indicate that focusing on mTOR to regulate immune cell-mediated inflammation could be a useful treatment target.

\subsection{Neuromuscular Blockade}

The neuromuscular blocking agents (NMBA) in sedation ARDS patients significantly improved the severe hypoxemia by decreasing patient-ventilator dyssynchrony, oxygen consumption and endogenous effort of breathing. The chest wall compliance was also improved under administration of NMBA. In a multicenter, double-blind trial [128], 340 ARDS patients was included and induced paralysis by either cisatracurium besylate. After received NMBA for $48 \mathrm{~h}$, the hazard ratio for death at 90 days was reduced. The incidence of complications was not different between NMBA and placebo group. In addition, NMBAs have anti-inflammatory effects to mild control the inflammatory response. However, NMBA-induced paralysis may increase the risk of acquired neuromuscular weakness leading to difficultly weaning from mechanical ventilation and increase mortality $[17,129,130]$.

\subsection{Vasodilators}

In some ARDS patients, the diffuse pulmonary vasoconstriction was found and contributed to change vascular permeability and induce severe hypoxemia. Administration of selective vasodilatations, such as inhaled nitric oxide (iNO), seem to improve gas exchange in ARDS patients. Inhaled nitric oxide, inducing pulmonary vasodilation and redistribution of pulmonary blood 
flow. The inhaled form minimized the adverse systemic hemodynamic effects. Many randomized controlled trials revealed transient improvement in oxygenation [102,131-133]. The similar result was reported in one meta-analysis [134]. The iNO may be a short-term therapy in severe ARDS patients, especially presenting hypoxemia and respiratory failure. Another inhaled pulmonary vasodilator agent, prostacycline, also improves oxygenation. However, the reduction of mortality in ARDS patients is no significant [135]. Although several pharmacologic therapies have been reported, they all had controversial effects or mediated only mild improvements to ARDS in clinical studies. In the future, randomized controlled trials are necessary to examine the safety and efficacy of novel pharmacologic agents.

\section{Conclusions}

In this review, we present the current clinical and basic research associated with the molecular regulation of inflammatory cells and cytokines in the pathogenesis of ARDS. Several concepts are worth reiterating. First, pneumonia and sepsis are the most common causes for ARDS. The Berlin criteria have improved our ability to predict ARDS-related mortality. Second, ARDS is characterized by 3 major phases. In the exudative phase, APCs trigger immune responses leading to epithelial and endothelial cell damage. Alveolar macrophages are important pulmonary APCs that interact with neutrophils via Toll-like receptors. Neutrophils cause NETosis and the release of growth factors and cytokines to induce vascular hyperpermeability, which causes alveolar edema. In the proliferative phase, the release of VEGF increases vascular permeability and exudation of protein-rich fluid. The ROS released downstream of inflammatory cytokines induce apoptosis and necroptosis in ARDS. In the fibroproliferative phase, some inflammatory responses are not resolved and develop into chronic inflammation, leading to fibrosing alveolitis with cystic changes by infiltrating macrophages, fibrocytes, fibroblasts, and myofibroblasts. The latest phase is characterized by remodeling of the lung architecture with fibrosis and honeycomb formation, which impair gas exchange. Finally, preventing tissue hypoperfusion and maintaining adequate gas exchange are critical in ARDS management. Although no effective treatments for ARDS have been reported, many pharmacologic therapies in Phase II and Phase III trials for ARDS are being continuously evaluated. The complicated mechanisms of molecular regulation in ARDS remain unclear. This review provides an overview of the recent clinical and basic molecular studies in ARDS, thereby constituting a strong foundation for the development of further therapeutic interventions.

Acknowledgments: This study was funded by grants RD106077 and RD106078 from Show-Chwan Memorial Hospital, Taiwan.

Author Contributions: Chin-Yao Yang and Chien-Sheng Chen wrote the paper; Giou-Teng Yiang contributed to the organization of figure; Yeung-Leung Cheng and Su-Boon Yong provided conceptual input; Meng-Yu Wu and Chia-Jung Li proofread and organized the manuscript. All authors reviewed the final version of the manuscript.

Conflicts of Interest: The authors declare no conflict of interest.

\begin{tabular}{ll}
\multicolumn{2}{l}{ Abbreviations } \\
AECC & American-european consensus conference \\
$\mathrm{AJ}$ & Adherens junction \\
$\mathrm{APC}$ & Antigen-presenting cell \\
$\mathrm{APC}$ & Antigen-presenting cells acute respiratory distress syndrome \\
$\mathrm{AQP}$ & Aquaporin \\
$\mathrm{ARDS}$ & Acute respiratory distress syndrome \\
$\mathrm{CPAP}$ & Continuous positive airway pressure \\
$\mathrm{FiO}_{2}$ & Inspiratory oxygen fraction \\
$\mathrm{IL}$ & Interleukin \\
$\mathrm{iNO}$ & Inhaled nitric oxide \\
$\mathrm{MLC}$ & Myosin light chain
\end{tabular}




$\begin{array}{ll}\text { MLKL } & \text { Mixed lineage kinase domain-like protein } \\ \text { MLCK } & \text { Myosin light chain kinase } \\ \text { MLCP } & \text { Myosin light chain phosphatase } \\ \text { NET } & \text { Eutrophil extracellular trap } \\ \text { NF- } k \mathrm{~B} & \text { Nuclear factor-kb } \\ \text { NKA } & \mathrm{N}^{+}-\mathrm{K}^{+} \text {-adenosine triphosphatase } \\ \mathrm{PaO}_{2} & \text { Arterial oxygen tension } \\ \mathrm{TNF} & \text { Tumor necrosis factor } \\ \text { PEEP } & \text { Positive end-expiratory pressure } \\ \mathrm{RIP3} & \text { Receptor-interacting protein kinase } 3 \\ \text { ROS } & \text { Reactive oxygen species } \\ \text { S1P } & \text { Sphingosine-1-phosphate } \\ \text { TGF } & \text { Transforming growth factor } \\ \text { TJs } & \text { Tight junctions } \\ \text { TNF } & \text { Tumor necrosis factor } \\ \text { VEGF } & \text { Vascular endothelial growth factor }\end{array}$

\section{References}

1. Lee, K.Y. Pneumonia, Acute Respiratory Distress Syndrome, and Early Immune-Modulator Therapy. Int. J. Mol. Sci. 2017, 18, 388. [CrossRef] [PubMed]

2. Ashbaugh, D.G.; Bigelow, D.B.; Petty, T.L.; Levine, B.E. Acute respiratory distress in adults. Lancet 1967, 2, 319-323. [CrossRef]

3. Abrams, D.; Brodie, D. Extracorporeal membrane oxygenation for adult respiratory failure: 2017 update. Chest 2017, 152, 639-649. [CrossRef] [PubMed]

4. Confalonieri, M.; Salton, F.; Fabiano, F. Acute respiratory distress syndrome. Eur. Respir. Rev. 2017, 26. [CrossRef] [PubMed]

5. Epelbaum, O.; Aronow, W.S. Mechanical ventilation in the acute respiratory distress syndrome. Hosp. Pract. 2017, 45, 88-98. [CrossRef] [PubMed]

6. Matthay, M.A.; McAuley, D.F.; Ware, L.B. Clinical trials in acute respiratory distress syndrome: Challenges and opportunities. Lancet Respir. Med. 2017, 5, 524-534. [CrossRef]

7. Meyer, N.J.; Calfee, C.S. Novel translational approaches to the search for precision therapies for acute respiratory distress syndrome. Lancet Respir. Med. 2017, 5, 512-523. [CrossRef]

8. Brower, R.G.; Lanken, P.N.; MacIntyre, N.; Matthay, M.A.; Morris, A.; Ancukiewicz, M.; Schoenfeld, D.; Thompson, B.T. Higher versus lower positive end-expiratory pressures in patients with the acute respiratory distress syndrome. N. Engl. J. Med. 2004, 351, 327-336. [PubMed]

9. Esteban, A.; Frutos-Vivar, F.; Muriel, A.; Ferguson, N.D.; Penuelas, O.; Abraira, V.; Raymondos, K.; Rios, F.; Nin, N.; Apezteguia, C.; et al. Evolution of mortality over time in patients receiving mechanical ventilation. Am. J. Respir. Crit. Care Med. 2013, 188, 220-230. [CrossRef] [PubMed]

10. Villar, J.; Blanco, J.; Anon, J.M.; Santos-Bouza, A.; Blanch, L.; Ambros, A.; Gandia, F.; Carriedo, D.; Mosteiro, F.; Basaldua, S.; et al. The Alien study: Incidence and outcome of acute respiratory distress syndrome in the era of lung protective ventilation. Intensive Care Med. 2011, 37, 1932-1941. [CrossRef] [PubMed]

11. Wang, C.Y.; Calfee, C.S.; Paul, D.W.; Janz, D.R.; May, A.K.; Zhuo, H.; Bernard, G.R.; Matthay, M.A.; Ware, L.B.; Kangelaris, K.N. One-year mortality and predictors of death among hospital survivors of acute respiratory distress syndrome. Intensive Care Med. 2014, 40, 388-396. [CrossRef] [PubMed]

12. Bellani, G.; Laffey, J.G.; Pham, T.; Fan, E.; Brochard, L.; Esteban, A.; Gattinoni, L.; van Haren, F.; Larsson, A.; McAuley, D.F.; et al. Epidemiology, patterns of care, and mortality for patients with acute respiratory distress syndrome in intensive care units in 50 countries. JAMA 2016, 315, 788-800. [CrossRef] [PubMed]

13. Bersten, A.D.; Edibam, C.; Hunt, T.; Moran, J. Incidence and mortality of acute lung injury and the acute respiratory distress syndrome in three Australian states. Am. J. Respir. Crit. Care Med. 2002, 165, 443-448. [CrossRef] [PubMed] 
14. Estenssoro, E.; Dubin, A.; Laffaire, E.; Canales, H.; Saenz, G.; Moseinco, M.; Pozo, M.; Gomez, A.; Baredes, N.; Jannello, G.; et al. Incidence, clinical course, and outcome in 217 patients with acute respiratory distress syndrome. Crit. Care Med. 2002, 30, 2450-2456. [CrossRef] [PubMed]

15. MacCallum, N.S.; Evans, T.W. Epidemiology of acute lung injury. Curr. Opin. Crit. Care 2005, 11, 43-49. [CrossRef] [PubMed]

16. Rubenfeld, G.D.; Caldwell, E.; Peabody, E.; Weaver, J.; Martin, D.P.; Neff, M.; Stern, E.J.; Hudson, L.D. Incidence and outcomes of acute lung injury. N. Engl. J. Med. 2005, 353, 1685-1693. [CrossRef] [PubMed]

17. Kim, W.Y.; Hong, S.B. Sepsis and acute respiratory distress syndrome: Recent update. Tuberc. Respir. Dis. (Seoul) 2016, 79, 53-57. [CrossRef] [PubMed]

18. Hudson, L.D.; Milberg, J.A.; Anardi, D.; Maunder, R.J. Clinical risks for development of the acute respiratory distress syndrome. Am. J. Respir. Crit. Care Med. 1995, 151, 293-301. [CrossRef] [PubMed]

19. Fanelli, V.; Vlachou, A.; Ghannadian, S.; Simonetti, U.; Slutsky, A.S.; Zhang, H. Acute respiratory distress syndrome: New definition, current and future therapeutic options. J. Thoracic Dis. 2013, 5, 326-334.

20. Bernard, G.R.; Artigas, A.; Brigham, K.L.; Carlet, J.; Falke, K.; Hudson, L.; Lamy, M.; Legall, J.R.; Morris, A.; Spragg, R. The American-European consensus conference on Ards. Definitions, mechanisms, relevant outcomes, and clinical trial coordination. Am. J. Respir. Crit. Care Med. 1994, 149, 818-824. [CrossRef] [PubMed]

21. Ferguson, N.D.; Fan, E.; Camporota, L.; Antonelli, M.; Anzueto, A.; Beale, R.; Brochard, L.; Brower, R.; Esteban, A.; Gattinoni, L.; et al. The Berlin definition of Ards: An expanded rationale, justification, and supplementary material. Intensive Care Med. 2012, 38, 1573-1582. [CrossRef] [PubMed]

22. Walkey, A.J.; Summer, R.; Ho, V.; Alkana, P. Acute respiratory distress syndrome: Epidemiology and management approaches. Clin. Epidemiol. 2012, 4, 159-169. [CrossRef] [PubMed]

23. Greco, E.; Lupia, E.; Bosco, O.; Vizio, B.; Montrucchio, G. Platelets and multi-organ failure in sepsis. Int. J. Mol. Sci. 2017, 18, 2200. [CrossRef] [PubMed]

24. Koh, Y. Update in acute respiratory distress syndrome. J. Intensive Care 2014, 2, 2. [CrossRef] [PubMed]

25. Sharp, C.; Millar, A.B.; Medford, A.R. Advances in understanding of the pathogenesis of acute respiratory distress syndrome. Respiration 2015, 89, 420-434. [CrossRef] [PubMed]

26. Ware, L.B.; Matthay, M.A. The acute respiratory distress syndrome. N. Engl. J. Med. 2000, 342, 1334-1349. [CrossRef] [PubMed]

27. Wu, M.-Y.; Li, C.-J.; Hou, M.-F.; Chu, P.-Y. New insights into the role of inflammation in the pathogenesis of atherosclerosis. Int. J. Mol. Sci. 2017, 18, 2034. [CrossRef] [PubMed]

28. Chavez, A.; Smith, M.; Mehta, D. Chapter six-New insights into the regulation of vascular permeability. In International Review of Cell and Molecular Biology; Jeon, K.W., Ed.; Academic Press: Cambridge, MA, USA, 2011; Volume 290, pp. 205-248.

29. Fujishima, S. Pathophysiology and biomarkers of acute respiratory distress syndrome. J. Intensive Care 2014, 2, 32. [CrossRef] [PubMed]

30. Garcia, J.G. Concepts in microvascular endothelial barrier regulation in health and disease. Microvasc. Res. 2009, 77, 1-3. [CrossRef] [PubMed]

31. Eklund, L.; Saharinen, P. Angiopoietin signaling in the vasculature. Exp. Cell Res. 2013, 319, 1271-1280. [CrossRef] [PubMed]

32. Wang, L.; Dudek, S.M. Regulation of vascular permeability by sphingosine 1-phosphate. Microvasc. Res. 2009, 77, 39-45. [CrossRef] [PubMed]

33. Kendrick, S.F.W.; Jones, D.E.J. Mechanisms of innate immunity in sepsis. In Sepsis; Baudouin, S.V., Ed.; Springer: London, UK, 2008; pp. 5-10.

34. Remick, D.G. Pathophysiology of sepsis. Am. J. Pathol. 2007, 170, 1435-1444. [CrossRef] [PubMed]

35. Barratt, S.; Medford, A.R.; Millar, A.B. Vascular endothelial growth factor in acute lung injury and acute respiratory distress syndrome. Respiration 2014, 87, 329-342. [CrossRef] [PubMed]

36. Azamfirei, L.; Gurzu, S.; Solomon, R.; Copotoiu, R.; Copotoiu, S.; Jung, I.; Tilinca, M.; Branzaniuc, K.; Corneci, D.; Szederjesi, J.; et al. Vascular endothelial growth factor: A possible mediator of endothelial activation in acute respiratory distress syndrome. Minerva Anestesiol. 2010, 76, 609-616. [PubMed]

37. Ourradi, K.; Blythe, T.; Jarrett, C.; Barratt, S.L.; Welsh, G.I.; Millar, A.B. Vegf isoforms have differential effects on permeability of human pulmonary microvascular endothelial cells. Respir. Res. 2017, 18, 116. [CrossRef] [PubMed] 
38. Matute-Bello, G.; Liles, W.C.; Steinberg, K.P.; Kiener, P.A.; Mongovin, S.; Chi, E.Y.; Jonas, M.; Martin, T.R. Soluble fas ligand induces epithelial cell apoptosis in humans with acute lung injury (Ards). J. Immunol. 1999, 163, 2217-2225. [PubMed]

39. Galani, V.; Tatsaki, E.; Bai, M.; Kitsoulis, P.; Lekka, M.; Nakos, G.; Kanavaros, P. The role of apoptosis in the pathophysiology of acute respiratory distress syndrome (Ards): An up-to-date cell-specific review. Pathol. Res. Pract. 2010, 206, 145-150. [CrossRef] [PubMed]

40. Fialkow, L.; Fochesatto Filho, L.; Bozzetti, M.C.; Milani, A.R.; Rodrigues Filho, E.M.; Ladniuk, R.M.; Pierozan, P.; de Moura, R.M.; Prolla, J.C.; Vachon, E.; et al. Neutrophil apoptosis: A marker of disease severity in sepsis and sepsis-induced acute respiratory distress syndrome. Crit. Care 2006, 10, R155. [CrossRef] [PubMed]

41. Pan, L.; Yao, D.C.; Yu, Y.Z.; Li, S.J.; Chen, B.J.; Hu, G.H.; Xi, C.; Wang, Z.H.; Wang, H.Y.; Li, J.H.; et al. Necrostatin-1 protects against Oleic acid-induced acute respiratory distress syndrome in rats. Biochem. Biophys. Res. Commun. 2016, 478, 1602-1608. [CrossRef] [PubMed]

42. Qing, D.Y.; Conegliano, D.; Shashaty, M.G.; Seo, J.; Reilly, J.P.; Worthen, G.S.; Huh, D.; Meyer, N.J.; Mangalmurti, N.S. Red blood cells induce necroptosis of lung endothelial cells and increase susceptibility to lung inflammation. Am. J. Respir. Crit. Care Med. 2014, 190, 1243-1254. [CrossRef] [PubMed]

43. Wang, L.; Wang, T.; Li, H.; Liu, Q.; Zhang, Z.; Xie, W.; Feng, Y.; Socorburam, T.; Wu, G.; Xia, Z.; et al. Receptor interacting protein 3-mediated necroptosis promotes lipopolysaccharide-induced inflammation and acute respiratory distress syndrome in mice. PLoS ONE 2016, 11, e0155723. [CrossRef] [PubMed]

44. Burnham, E.L.; Janssen, W.J.; Riches, D.W.H.; Moss, M.; Downey, G.P. The fibroproliferative response in acute respiratory distress syndrome: Mechanisms and clinical significance. Eur. Respir. J. 2014, 43, $276-285$. [CrossRef] [PubMed]

45. Hamada, N.; Kuwano, K.; Yamada, M.; Hagimoto, N.; Hiasa, K.; Egashira, K.; Nakashima, N.; Maeyama, T.; Yoshimi, M.; Nakanishi, Y. Anti-vascular endothelial growth factor gene therapy attenuates lung injury and fibrosis in mice. J. Immunol. 2005, 175, 1224-1231. [CrossRef] [PubMed]

46. Keane, M.P.; Belperio, J.A.; Moore, T.A.; Moore, B.B.; Arenberg, D.A.; Smith, R.E.; Burdick, M.D.; Kunkel, S.L.; Strieter, R.M. Neutralization of the Cxc chemokine, macrophage inflammatory protein-2, attenuates bleomycin-induced pulmonary fibrosis. J. Immunol. 1999, 162, 5511-5518. [PubMed]

47. Ou, X.M.; Li, W.C.; Liu, D.S.; Li, Y.P.; Wen, F.Q.; Feng, Y.L.; Zhang, S.F.; Huang, X.Y.; Wang, T.; Wang, K.; et al. Vegfr-2 antagonist Su5416 attenuates bleomycin-induced pulmonary fibrosis in mice. Int. Immunopharmacol. 2009, 9, 70-79. [CrossRef] [PubMed]

48. Parikh, S.M.; Mammoto, T.; Schultz, A.; Yuan, H.T.; Christiani, D.; Karumanchi, S.A.; Sukhatme, V.P. Excess circulating angiopoietin-2 may contribute to pulmonary vascular leak in sepsis in humans. PLoS Med. 2006, 3, e46. [CrossRef] [PubMed]

49. Network, T.A.R.D.S. Ventilation with lower tidal volumes as compared with traditional tidal volumes for acute lung injury and the acute respiratory distress syndrome. N. Engl. J. Med. 2000, 342, 1301-1308.

50. Tremblay, L.N.; Slutsky, A.S. Ventilator-induced lung injury: From the bench to the bedside. Intensive Care Med. 2006, 32, 24-33. [CrossRef] [PubMed]

51. Pelosi, P.; Rocco, P.R. Effects of Mechanical Ventilation on the Extracellular Matrix. Intensive Care Med 2008, 34, 631-639. [CrossRef] [PubMed]

52. Tremblay, L.N.; Miatto, D.; Hamid, Q.; Govindarajan, A.; Slutsky, A.S. Injurious ventilation induces widespread pulmonary epithelial expression of tumor necrosis factor-alpha and interleukin-6 messenger RNA. Crit. Care Med. 2002, 30, 1693-1700. [CrossRef] [PubMed]

53. Capelozzi, V.L.; Allen, T.C.; Beasley, M.B.; Cagle, P.T.; Guinee, D.; Hariri, L.P.; Husain, A.N.; Jain, D.; Lantuejoul, S.; Larsen, B.T.; et al. Molecular and immune biomarkers in acute respiratory distress syndrome: A perspective from members of the pulmonary pathology society. Arch. Pathol. Lab. Med. 2017, 141, 1719-1727. [CrossRef] [PubMed]

54. Aggarwal, N.R.; King, L.S.; D'Alessio, F.R. Diverse macrophage populations mediate acute lung inflammation and resolution. Am. J. Physiol. Lung Cell Mol. Physiol. 2014, 306, L709-L725. [CrossRef] [PubMed]

55. Han, S.H.; Mallampalli, R.K. The acute respiratory distress syndrome: From mechanism to translation. J. Immunol. 2015, 194, 855-860. [CrossRef] [PubMed]

56. D'Alessio, F.R.; Craig, J.M.; Singer, B.D.; Files, D.C.; Mock, J.R.; Garibaldi, B.T.; Fallica, J.; Tripathi, A.; Mandke, P.; Gans, J.H.; et al. Enhanced resolution of experimental Ards through Il-4-mediated lung macrophage reprogramming. Am. J. Physiol. Lung Cell Mol. Physiol. 2016, 310, L733-L746. [CrossRef] [PubMed] 
57. Norman, J.G.; Fink, G.W.; Franz, M.G. Acute pancreatitis induces intrapancreatic tumor necrosis factor gene expression. Arch. Surg. 1995, 130, 966-970. [CrossRef] [PubMed]

58. Cohen, J. The immunopathogenesis of sepsis. Nature 2002, 420, 885-891. [CrossRef] [PubMed]

59. Wrigge, H.; Stüber, F.; Putensen, C. Ventilator-associated systemic inflammation. In Yearbook of Intensive Care and Emergency Medicine 2001; Vincent, J.-L., Ed.; Springer: Berlin/Heidelberg, Germany, 2001; pp. $35-43$.

60. Park, W.Y.; Goodman, R.B.; Steinberg, K.P.; Ruzinski, J.T.; Radella, F., 2nd; Park, D.R.; Pugin, J.; Skerrett, S.J.; Hudson, L.D.; Martin, T.R. Cytokine balance in the lungs of patients with acute respiratory distress syndrome. Am. J. Respir. Crit. Care Med. 2001, 164, 1896-1903. [CrossRef] [PubMed]

61. Siler, T.M.; Swierkosz, J.E.; Hyers, T.M.; Fowler, A.A.; Webster, R.O. Immunoreactive interleukin-1 in bronchoalveolar lavage fluid of high-risk patients and patients with the adult respiratory distress syndrome. Exp. Lung Res. 1989, 15, 881-894. [CrossRef] [PubMed]

62. Giri, S.N.; Hyde, D.M.; Hollinger, M.A. Effect of antibody to transforming growth factor beta on bleomycin induced accumulation of lung collagen in mice. Thorax 1993, 48, 959-966. [CrossRef] [PubMed]

63. Ihn, H. Pathogenesis of fibrosis: Role of Tgf-Beta and Ctgf. Curr. Opin. Rheumatol. 2002, 14, 681-685. [CrossRef] [PubMed]

64. Shull, M.M.; Ormsby, I.; Kier, A.B.; Pawlowski, S.; Diebold, R.J.; Yin, M.; Allen, R.; Sidman, C.; Proetzel, G.; Calvin, D.; et al. Targeted disruption of the mouse transforming growth factor-beta 1 gene results in multifocal inflammatory disease. Nature 1992, 359, 693-699. [CrossRef] [PubMed]

65. Broekelmann, T.J.; Limper, A.H.; Colby, T.V.; McDonald, J.A. Transforming growth factor beta 1 is present at sites of extracellular matrix gene expression in human pulmonary fibrosis. Proc. Natl. Acad. Sci. USA 1991, 88, 6642-6646. [CrossRef] [PubMed]

66. Howard, M.; O'Garra, A. Biological properties of interleukin 10. Immunol. Today 1992, 13, 198-200. [CrossRef]

67. Smith, S.R.; Terminelli, C.; Kenworthy-Bott, L.; Calzetta, A.; Donkin, J. The cooperative effects of Tnf-alpha and Ifn-gamma are determining factors in the ability of Il-10 to protect mice from lethal endotoxemia. J. Leukoc. Biol. 1994, 55, 711-718. [CrossRef] [PubMed]

68. Fiorentino, D.F.; Zlotnik, A.; Mosmann, T.R.; Howard, M.; O'Garra, A. Il-10 inhibits cytokine production by activated macrophages. J. Immunol. 1991, 147, 3815-3822. [PubMed]

69. Kasama, T.; Strieter, R.M.; Lukacs, N.W.; Burdick, M.D.; Kunkel, S.L. Regulation of neutrophil-derived chemokine expression by Il-10. J. Immunol. 1994, 152, 3559-3569. [PubMed]

70. Lo, C.-J.; Fu, M.; Cryer, H.G. Interleukin 10 inhibits alveolar macrophage production of inflammatory mediators involved in adult respiratory distress syndrome. J. Surg. Res. 1998, 79, 179-184. [CrossRef] [PubMed]

71. Armstrong, L.; Millar, A.B. Relative production of tumour necrosis factor alpha and interleukin 10 in adult respiratory distress syndrome. Thorax 1997, 52, 442-446. [CrossRef] [PubMed]

72. Miller, E.J.; Cohen, A.B.; Nagao, S.; Griffith, D.; Maunder, R.J.; Martin, T.R.; Weiner-Kronish, J.P.; Sticherling, M.; Christophers, E.; Matthay, M.A. Elevated levels of nap-1/interleukin-8 are present in the airspaces of patients with the adult respiratory distress syndrome and are associated with increased mortality. Am. Rev. Respir. Dis. 1992, 146, 427-432. [CrossRef] [PubMed]

73. Olson, T.S.; Ley, K. Chemokines and chemokine receptors in leukocyte trafficking. Am. J. Physiol. Regul. Integr. Comp. Physiol. 2002, 283, R7-R28. [CrossRef] [PubMed]

74. Puneet, P.; Moochhala, S.; Bhatia, M. Chemokines in acute respiratory distress syndrome. Am. J. Physiol. Lung Cell Mol. Physiol. 2005, 288, L3-L15. [CrossRef] [PubMed]

75. Cummings, C.J.; Martin, T.R.; Frevert, C.W.; Quan, J.M.; Wong, V.A.; Mongovin, S.M.; Hagen, T.R.; Steinberg, K.P.; Goodman, R.B. Expression and function of the chemokine receptors Cxcr1 and Cxcr2 in sepsis. J. Immunol. 1999, 162, 2341-2346. [PubMed]

76. Chishti, A.D.; Dark, J.H.; Kesteven, P.; Powell, H.; Snowden, C.; Shenton, B.K.; Kirby, J.A.; Baudouin, S.V. Expression of chemokine receptors Cxcr1 and Cxcr2 during cardiopulmonary bypass. J. Thoracic Cardiovasc. Surg. 2001, 122, 1162-1166. [CrossRef] [PubMed]

77. Stillie, R.; Farooq, S.M.; Gordon, J.R.; Stadnyk, A.W. The functional significance behind expressing two Il-8 receptor types on Pmn. J. Leukoc. Biol. 2009, 86, 529-543. [CrossRef] [PubMed]

78. Summers, C.; Singh, N.R.; White, J.F.; Mackenzie, I.M.; Johnston, A.; Solanki, C.; Balan, K.K.; Peters, A.M.; Chilvers, E.R. Pulmonary retention of primed neutrophils: A novel protective host response, which is impaired in the acute respiratory distress syndrome. Thorax 2014, 69, 623-629. [CrossRef] [PubMed] 
79. Grommes, J.; Soehnlein, O. Contribution of neutrophils to acute lung injury. Mol. Med. 2011, 17, $293-307$. [CrossRef] [PubMed]

80. Buczek-Thomas, J.A.; Lucey, E.C.; Stone, P.J.; Chu, C.L.; Rich, C.B.; Carreras, I.; Goldstein, R.H.; Foster, J.A.; Nugent, M.A. Elastase mediates the release of growth factors from lung in vivo. Am. J. Respir. Cell Mol. Biol. 2004, 31, 344-350. [CrossRef] [PubMed]

81. Suzuki, T.; Yamashita, C.; Zemans, R.L.; Briones, N.; Van Linden, A.; Downey, G.P. Leukocyte elastase induces lung epithelial apoptosis via a Par-1-, Nf-kb-, and P53-dependent pathway. Am. J. Respir. Cell Mol. Biol. 2009, 41, 742-755. [CrossRef] [PubMed]

82. Chen, H.C.; Lin, H.C.; Liu, C.Y.; Wang, C.H.; Hwang, T.; Huang, T.T.; Lin, C.H.; Kuo, H.P. Neutrophil elastase induces Il-8 synthesis by lung epithelial cells via the mitogen-activated protein kinase pathway. J. Biomed. Sci. 2004, 11, 49-58. [CrossRef] [PubMed]

83. Witherden, I.R.; Vanden Bon, E.J.; Goldstraw, P.; Ratcliffe, C.; Pastorino, U.; Tetley, T.D. Primary human alveolar type II epithelial cell chemokine release: Effects of cigarette smoke and neutrophil elastase. Am. J. Respir. Cell Mol. Biol. 2004, 30, 500-509. [CrossRef] [PubMed]

84. Kaplan, M.J. Neutrophil extracellular traps (nets): Double-edged swords of innate immunity. J. Immunol. 2012, 189, 2689-2695. [CrossRef] [PubMed]

85. Brinkmann, V.; Reichard, U.; Goosmann, C.; Fauler, B.; Uhlemann, Y.; Weiss, D.S.; Weinrauch, Y.; Zychlinsky, A. Neutrophil extracellular traps kill bacteria. Science 2004, 303, 1532-1535. [CrossRef] [PubMed]

86. Dejana, E. Endothelial cell-cell junctions: Happy together. Nat. Rev. Mol. Cell Biol. 2004, 5, 261-270. [CrossRef] [PubMed]

87. Wennerberg, K.; Rossman, K.L.; Der, C.J. The ras superfamily at a glance. J. Cell Sci. 2005, 118, 843-846. [CrossRef] [PubMed]

88. Bustelo, X.R.; Sauzeau, V.; Berenjeno, I.M. Gtp-binding proteins of the Rho/Rac family: Regulation, effectors and functions in vivo. Bioessays 2007, 29, 356-370. [CrossRef] [PubMed]

89. Medzhitov, R. Toll-like receptors and innate immunity. Nat. Rev. Immunol. 2001, 1, 135-145. [CrossRef] [PubMed]

90. Amano, M.; Nakayama, M.; Kaibuchi, K. Rho-kinase/rock: A key regulator of the cytoskeleton and cell polarity. Cytoskeleton 2010, 67, 545-554. [CrossRef] [PubMed]

91. Sawafuji, M.; Ishizaka, A.; Kohno, M.; Koh, H.; Tasaka, S.; Ishii, Y.; Kobayashi, K. Role of rho-kinase in reexpansion pulmonary edema in rabbits. Am. J. Physiol. Lung Cell Mol. Physiol. 2005, 289, L946-L953. [CrossRef] [PubMed]

92. Paszti-Gere, E.; Csibrik-Nemeth, E.; Szeker, K.; Csizinszky, R.; Jakab, C.; Galfi, P. Acute oxidative stress affects Il-8 and Tnf-alpha expression in Ipec-J2 porcine epithelial cells. Inflammation 2012, 35, 994-1004. [CrossRef] [PubMed]

93. Soini, Y. Claudins in lung diseases. Respir. Res. 2011, 12, 70. [CrossRef] [PubMed]

94. Overgaard, C.E.; Daugherty, B.L.; Mitchell, L.A.; Koval, M. Claudins: Control of barrier function and regulation in response to oxidant stress. Antioxid. Redox. Signal. 2011, 15, 1179-1193. [CrossRef] [PubMed]

95. Figueira, E.R.; Bacchella, T.; Coelho, A.M.; Sampietre, S.N.; Molan, N.A.; Leitao, R.M.; Machado, M.C. Timing-dependent protection of hypertonic saline solution administration in experimental liver ischemia/reperfusion injury. Surgery 2010, 147, 415-423. [CrossRef] [PubMed]

96. Lucas, R.; Verin, A.D.; Black, S.M.; Catravas, J.D. Regulators of endothelial and epithelial barrier integrity and function in acute lung injury. Biochem. Pharmacol. 2009, 77, 1763-1772. [CrossRef] [PubMed]

97. Rokkam, D.; Lafemina, M.J.; Lee, J.W.; Matthay, M.A.; Frank, J.A. Claudin-4 levels are associated with intact alveolar fluid clearance in human lungs. Am. J. Pathol. 2011, 179, 1081-1087. [CrossRef] [PubMed]

98. Montgomery, A.B.; Stager, M.A.; Carrico, C.J.; Hudson, L.D. Causes of mortality in patients with the adult respiratory distress syndrome. Am. Rev. Respir. Dis. 1985, 132, 485-489. [CrossRef] [PubMed]

99. Bell, R.C.; Coalson, J.J.; Smith, J.D.; Johanson, W.G., Jr. Multiple organ system failure and infection in adult respiratory distress syndrome. Ann. Internal Med. 1983, 99, 293-298. [CrossRef]

100. Anzueto, A.; Baughman, R.P.; Guntupalli, K.K.; Weg, J.G.; Wiedemann, H.P.; Raventos, A.A.; Lemaire, F.; Long, W.; Zaccardelli, D.S.; Pattishall, E.N. Aerosolized surfactant in adults with sepsis-induced acute respiratory distress syndrome. Exosurf acute respiratory distress syndrome sepsis study group. N. Engl. J. Med. 1996, 334, 1417-1421. [CrossRef] [PubMed] 
101. Khilnani, G.; Hadda, V. Corticosteroids and Ards: A review of treatment and prevention evidence. Lung India 2011, 28, 114-119. [CrossRef] [PubMed]

102. Taylor, R.W.; Zimmerman, J.L.; Dellinger, R.P.; Straube, R.C.; Criner, G.J.; Davis, K., Jr.; Kelly, K.M.; Smith, T.C.; Small, R.J. Low-dose inhaled nitric oxide in patients with acute lung injury: A randomized controlled trial. JAMA 2004, 291, 1603-1609. [CrossRef] [PubMed]

103. Milberg, J.A.; Davis, D.R.; Steinberg, K.P.; Hudson, L.D. Improved survival of patients with acute respiratory distress syndrome (Ards): 1983-1993. JAMA 1995, 273, 306-309. [CrossRef] [PubMed]

104. Abel, S.J.; Finney, S.J.; Brett, S.J.; Keogh, B.F.; Morgan, C.J.; Evans, T.W. Reduced mortality in association with the acute respiratory distress syndrome (Ards). Thorax 1998, 53, 292-294. [CrossRef] [PubMed]

105. Needham, D.M.; Colantuoni, E.; Mendez-Tellez, P.A.; Dinglas, V.D.; Sevransky, J.E.; Dennison Himmelfarb, C.R.; Desai, S.V.; Shanholtz, C.; Brower, R.G.; Pronovost, P.J. Lung protective mechanical ventilation and two year survival in patients with acute lung injury: Prospective cohort study. BMJ 2012, 344, e2124. [CrossRef] [PubMed]

106. Manzano, F.; Fernandez-Mondejar, E.; Colmenero, M.; Poyatos, M.E.; Rivera, R.; Machado, J.; Catalan, I.; Artigas, A. Positive-end expiratory pressure reduces incidence of ventilator-associated pneumonia in nonhypoxemic patients. Crit. Care Med. 2008, 36, 2225-2231. [CrossRef] [PubMed]

107. Gattinoni, L.; Pelosi, P.; Crotti, S.; Valenza, F. Effects of positive end-expiratory pressure on regional distribution of tidal volume and recruitment in adult respiratory distress syndrome. Am. J. Respir. Crit. Care Med. 1995, 151, 1807-1814. [CrossRef] [PubMed]

108. Caironi, P.; Cressoni, M.; Chiumello, D.; Ranieri, M.; Quintel, M.; Russo, S.G.; Cornejo, R.; Bugedo, G.; Carlesso, E.; Russo, R.; et al. Lung opening and closing during ventilation of acute respiratory distress syndrome. Am. J. Respir. Crit. Care Med. 2010, 181, 578-586. [CrossRef] [PubMed]

109. Meade, M.O.; Cook, D.J.; Guyatt, G.H.; Slutsky, A.S.; Arabi, Y.M.; Cooper, D.J.; Davies, A.R.; Hand, L.E.; Zhou, Q.; Thabane, L.; et al. Ventilation strategy using low tidal volumes, recruitment maneuvers, and high positive end-expiratory pressure for acute lung injury and acute respiratory distress syndrome: A randomized controlled trial. JAMA 2008, 299, 637-645. [CrossRef] [PubMed]

110. Lamontagne, F.; Brower, R.; Meade, M. Corticosteroid therapy in acute respiratory distress syndrome. CMAJ 2013, 185, 216-221. [CrossRef] [PubMed]

111. Belvitch, P.; Dudek, S.M. Corticosteroids and Ards: The debate continues. Crit. Care Med. 2013, 41, $1813-1814$. [CrossRef] [PubMed]

112. Thompson, B.T. Corticosteroids in Ards. N. Engl. J. Med. 2006, 355, 316-319.

113. Greaves, M.W. Anti-inflammatory action of corticosteroids. Postgrad. Med. J. 1976, 52, 631-633. [CrossRef] [PubMed]

114. Rhen, T.; Cidlowski, J.A. Antiinflammatory action of glucocorticoids-New mechanisms for old drugs. N. Engl. J. Med. 2005, 353, 1711-1723. [CrossRef] [PubMed]

115. Meduri, G.U.; Marik, P.E.; Chrousos, G.P.; Pastores, S.M.; Arlt, W.; Beishuizen, A.; Bokhari, F.; Zaloga, G.; Annane, D. Steroid treatment in Ards: A critical appraisal of the Ards network trial and the recent literature. Intensive Care Med. 2008, 34, 61-69. [CrossRef] [PubMed]

116. Tang, B.M.; Craig, J.C.; Eslick, G.D.; Seppelt, I.; McLean, A.S. Use of corticosteroids in acute lung injury and acute respiratory distress syndrome: A systematic review and meta-analysis. Crit. Care Med. 2009, 37, 1594-1603. [CrossRef] [PubMed]

117. Steinberg, K.P.; Hudson, L.D.; Goodman, R.B.; Hough, C.L.; Lanken, P.N.; Hyzy, R.; Thompson, B.T.; Ancukiewicz, M. Efficacy and safety of corticosteroids for persistent acute respiratory distress syndrome. N. Engl. J. Med. 2006, 354, 1671-1684. [PubMed]

118. Bernard, G.R.; Luce, J.M.; Sprung, C.L.; Rinaldo, J.E.; Tate, R.M.; Sibbald, W.J.; Kariman, K.; Higgins, S.; Bradley, R.; Metz, C.A.; et al. High-dose corticosteroids in patients with the adult respiratory distress syndrome. N. Engl. J. Med. 1987, 317, 1565-1570. [CrossRef] [PubMed]

119. Fyhrquist, F; Metsarinne, K.; Tikkanen, I. Role of angiotensin II in blood pressure regulation and in the pathophysiology of cardiovascular disorders. J. Hum. Hypertens. 1995, 9 (Suppl. 5), S19-S24. [PubMed]

120. Cooper, C.L.; Shaffer, J.E.; Malik, K.U. Mechanism of action of angiotensin ii and bradykinin on prostaglandin synthesis and vascular tone in the isolated rat kidney. Effect of ca++ antagonists and calmodulin inhibitors. Circ. Res. 1985, 56, 97-108. [CrossRef] [PubMed] 
121. Puscas, I.; Coltau, M.; Gilau, L.; Baican, M.; Pasca, R.; Domuta, G.; Hecht, A. The mechanism of action of angiotensin II is dependent on direct activation of vascular smooth muscle carbonic anhydrase I. Int. J. Clin. Lab. Res. 2000, 30, 119-125. [CrossRef] [PubMed]

122. Chawla, L.S.; Busse, L.W.; Brasha-Mitchell, E.; Alotaibi, Z. The use of angiotensin II in distributive shock. Crit. Care 2016, 20, 137. [CrossRef] [PubMed]

123. Orfanos, S.E.; Armaganidis, A.; Glynos, C.; Psevdi, E.; Kaltsas, P.; Sarafidou, P.; Catravas, J.D.; Dafni, U.G.; Langleben, D.; Roussos, C. Pulmonary capillary endothelium-bound angiotensin-converting enzyme activity in acute lung injury. Circulation 2000, 102, 2011-2018. [CrossRef] [PubMed]

124. Elder, J. The renin-angiotensin system: A potential therapeutic target in Ards? Thorax 2005, 60, 821.

125. Zhao, Y.; Zhang, X.; Song, Z.; Qi, D.; Deng, X.; Xia, J.; He, J.; Deng, W.; Zhong, X.; Zhang, C.; et al. Rapamycin Attenuates Acute Lung Injury Induced by Lps through Inhibition of Th17 Cell Proliferation in Mice. Sci. Rep. 2016, 6, 20156.

126. Yang, Q.; Guan, K.L. Expanding Mtor Signaling. Cell Res 2007, 17, 666-681. [CrossRef] [PubMed]

127. Powell, J.D.; Pollizzi, K.N.; Heikamp, E.B.; Horton, M.R. Regulation of Immune Responses by Mtor. Annu. Rev. Immunol. 2012, 30, 39-68. [CrossRef] [PubMed]

128. Papazian, L.; Forel, J.-M.; Gacouin, A.; Penot-Ragon, C.; Perrin, G.; Loundou, A.; Jaber, S.; Arnal, J.-M.; Perez, D.; Seghboyan, J.-M.; et al. Neuromuscular blockers in early acute respiratory distress syndrome. N. Engl. J. Med. 2010, 363, 1107-1116. [CrossRef] [PubMed]

129. Sweeney, R.M.; McAuley, D.F. Acute respiratory distress syndrome. Lancet 2016, 388, 2416-2430. [CrossRef]

130. Umbrello, M.; Formenti, P.; Bolgiaghi, L.; Chiumello, D. Current concepts of Ards: A narrative review. Int. J. Mol. Sci. 2017, 18, 64. [CrossRef] [PubMed]

131. Dellinger, R.P.; Zimmerman, J.L.; Taylor, R.W.; Straube, R.C.; Hauser, D.L.; Criner, G.J.; Davis, K., Jr.; Hyers, T.M.; Papadakos, P. Effects of inhaled nitric oxide in patients with acute respiratory distress syndrome: Results of a randomized phase II trial. Inhaled nitric oxide in Ards study group. Crit. Care Med. 1998, 26, 15-23. [CrossRef] [PubMed]

132. Troncy, E.; Collet, J.P.; Shapiro, S.; Guimond, J.G.; Blair, L.; Ducruet, T.; Francoeur, M.; Charbonneau, M.; Blaise, G. Inhaled nitric oxide in acute respiratory distress syndrome: A pilot randomized controlled study. Am. J. Respir. Crit. Care Med. 1998, 157, 1483-1488. [CrossRef] [PubMed]

133. Michael, J.R.; Barton, R.G.; Saffle, J.R.; Mone, M.; Markewitz, B.A.; Hillier, K.; Elstad, M.R.; Campbell, E.J.; Troyer, B.E.; Whatley, R.E.; et al. Inhaled nitric oxide versus conventional therapy: Effect on oxygenation in Ards. Am. J. Respir. Crit. Care Med. 1998, 157, 1372-1380. [CrossRef] [PubMed]

134. Adhikari, N.K.J.; Burns, K.E.A.; Friedrich, J.O.; Granton, J.T.; Cook, D.J.; Meade, M.O. Effect of nitric oxide on oxygenation and mortality in acute lung injury: Systematic review and meta-analysis. BMJ 2007, 334, 779. [CrossRef] [PubMed]

135. Heard, S.O.; Longtine, K.; Toth, I.; Puyana, J.C.; Potenza, B.; Smyrnios, N. The influence of liposome-encapsulated prostaglandin E1 on hydrogen peroxide concentrations in the exhaled breath of patients with the acute respiratory distress syndrome. Anesth. Analg. 1999, 89, 353-357. [PubMed]

(C) 2018 by the authors. Licensee MDPI, Basel, Switzerland. This article is an open access article distributed under the terms and conditions of the Creative Commons Attribution (CC BY) license (http:/ / creativecommons.org/licenses/by/4.0/). 